\begin{tabular}{|l|l|r|}
\hline Volume 17 & No. 1, Mei 2021 & Halaman 30-44 \\
\hline
\end{tabular}

\title{
CITRA PEREMPUAN DALAM KUMPULAN PUISI IBU MENDULANG ANAK BERLARI KARYA CYNTHA HARIADI \\ (W omen's Image in Ibu Mendulang Anak Berlari Poetry Collection by Cyntha Hariadi)
}

\author{
Anna Wandira, Alfian Rokhmansyah, \& Irma Surayya Hanum \\ Fakultas Ilmu Budaya, Universitas Mulawarman \\ Jalan Ki Hajar Dewantara, Samarinda, Kalimantan Timur, Indonesia \\ * Pos-el: alfian.rokhmansyah@gmail.com
}

(Diterima: 15 November 2020; Direvisi: 27 November 2020; Disetujui: 9 Maret 2021)

\begin{abstract}
This study aimed to uncover the image of women in a collection of poems Ibu Mendulang Anak Berlari by Cyntha Hariadi, which includes physical images, psychological images, and social images of women. Descriptive qualitative research was used in this study. Data were quotations that allegedly contained images of women. Data collected by reading and note taking techniques. Data were analyzed by using a retroactive (hermeneutic) analysis technique to obtain an in-depth overview of the issues raised. The results showed that the physical image of women was found in 6 poems. Women's physical image included the depiction of a biological female organ during the process of pregnancy, childbirth, and breastfeeding her child. Women's psychic images were found in 17 poems. Psychic image of women included sportrayals of women who experience psychological states such as feeling sad, anxious, afraid, happy and othe remotional states. Women's social image was found in 6 poems. Women's social image included the depiction of women as social creatures and their role in the family and society.
\end{abstract}

Keywords: women's physical images; women's psychic images; women's social images; poetry collections

\begin{abstract}
Abstrak
Penelitian ini bertujuan untuk mengungkap citra perempuan dalam kumpulan puisi Ibu Mendulang Anak Berlari karya Cyntha Hariadi, yang meliputi citra fisik, citra psikis, dan citra sosial perempuan. Penelitian ini merupakan penelitian kualitatif desktiptif. Data berupa kutipan-kutipan yang diduga mengandung citra perempuan. Data dikumpulkan dengan teknik baca dan catat. Data dianalisis dengan menggunakan teknik analisis pembacaan retroaktif (hermeneutik) untuk memperoleh gambaran secara mendalam mengenai persoalan yang diangkat. Hasil penelitian menunjukkan bahwa citra fisik perempuan ditemukan pada 6 puisi. Citra fisik perempuan meliputi penggambaran organ biologis perempuan saat mengalami proses kehamilan, persalinan, serta menyusui anaknya. Citra psikis perempuan ditemukan pada 17 puisi. Citra psikis perempuan meliputi penggambaran perempuan yang mengalami keadaan psikis seperti merasa sedih, cemas, takut, gembira dan keadaan emosional lainnya. Citra sosial perempuan ditemukan pada 6 puisi. Citra sosial perempuan meliputi penggambaran perempuan sebagai makhluk sosial serta perannya dalam keluarga dan masyarakat.
\end{abstract}

Kata-kata kunci: citra fisik perempuan; citra psikis perempuan; citra sosial perempuan; kumpulan puisi

DOI: 10.26499/jk.v17i1.1847

How to cite: Wandira, A., Rokhmansyah, A., \& Hanum, I. S. (2021). Citra perempuan dalam kumpulan puisi ibu mendulang anak berlari karya cyntha hariadi. Kandai, 17(1), 30-44 (DOI: 10.26499/jk.v17i1.1847) 


\section{PENDAHULUAN}

Persoalan ketidakadilan gender umumya menimpa kaum perempuan. Persoalan demikian juga dirasakan oleh perempuan Indonesia. Perempuan Indonesia pada saat ini harus hidup pada posisi dilematis, khususnya pada perempuan yang berkarier (Syahrul, 2013). Perempuan yang semata-mata diposisikan pada peran domestik dan reproduksi sangat menghambat kemajuan mereka menggeluti dunia publik dan produksi. Hal tersebut merupakan rekayasa kultur dan tradisi yang menciptakan pelabelan atau stereotip tertentu pada perempuan yang telah mengakar kuat dalam masyarakat. Budaya dan tradisi sangat berperan dalam membentuk stereotip yang menciptakan ketergantungan perempuan pada laki-laki cukup besar. Untuk mereposisi peran perempuan dalam pergaulan sosial masyarakat, konsep gender lahir guna merekonstruksi hubungan laki-laki dan perempuan secara universal untuk membuka peluang yang sama menggeluti berbagai bidang kehidupan tanpa dipengaruhi oleh perbedaan gender, laki-laki dan perempuan (Rokhmansyah, 2016).

Dalam era modernisasi dan globalisasi, posisi perempuan tidak saja tersubordinasi, tetapi juga makin tertindas dan rentan terhadap proses eksploitasi, komodifikasi, serta kekerasan, baik dalam lingkup publik maupun pribadi. Perempuan dianggap tidak mempunyai hak untuk mendapatkan pendidikan, perempuan harus tinggal di rumah saja dan tidak mempunyai andil dalam kehidupan masyarakat, dipaksa kawin dan ditindak, diwarisi dan tidak mewarisi, dikuasai dan tidak pemah menguasai. Apabila ada yang memberikan kekayaan kepada mereka, mereka tidak boleh membelanjakan tanpa seizin suami karena suami selalu beranggapan bahwa merekalah yang paling berhak membelanjakan kekayaan itu (Wendra, 2010).

Salah satu penyair Indonesia yang mengangkat tema perempuan adalah Cyntha Hariadi. Kumpulan puisi karangannya yang berjudul $I b u$ Mendulang Anak Berlari memenangi lomba sayembara puisi yang diadakan Dewan Kesenian Jakarta pada tahun 2015. Ia memeroleh juara III dalam lomba tersebut. Puisi-puisi dalam kumpulan puisi tersebut berjumlah sebanyak 62 puisi, dan 87 halaman yang diterbitkan oleh PT Gramedia Pustaka Utama.

Kumpulan puisi Ibu Mendulang Anak Berlari karya Cyntha Hariadi merupakan objek dalam penelitian ini. Puisi-puisi dalam kumpulan puisi tersebut secara garis besar menggambarkan perempuan yang berstatuskan ibu dan mempunyai pengalaman menjadi ibu dalam arti sesungguhnya, yakni perempuan mengalami kodrat atau keadaan biologis seperti mengandung, melahirkan, dan menyusui. Selain mengalami keadaan biologis sebagai perempuan, puisi-puisi dalam kumpulan puisi tersebut juga menggambarkan sifat perempuan yang penyabar, rela berkorban, dan patuh pada urusan rumah tangga, baik dalam mengasuh anak serta melayani suami. Puisi-puisi dalam kumpulan puisi tersebut juga menggambarkan bagaimana beratnya menjadi ibu yang harus memenuhi ruang kerja ganda, baik dalam sektor publik dan domestik, tetapi tetap bertanggung jawab penuh dalam keluarga.

Penelitian terdahulu yang juga menganalisis kumpulan puisi $I b u$ Mendulang Anak Berlari karya Cyntha Hariadi ialah oleh Putri (2019) dan 
Novena, Suhita, \& Suryanto (2020). Penelitian Putri (2019) berjudul“" Kompleksitas Makna Pengibuan (Kajian Teks Kumpulan Puisi Ibu Mendulang Anak Berlari Karya Cyntha Hariadi)" berfokus pada deskrispsi (1) relasi ibu dan anak yang terdapat pada enam puisi dalam kumpulan puisi Ibu Mendulang Anak Berlari, dan (2) pemaknaan ibu terhadap dirinya pada enam judul puisi dalam kumpulan puisi Ibu Mendulang Anak Berlari. Pada penelitiannya tersebut, Putri menggunakan konsep semiotic language yang dipaparkan oleh Kristeva dengan fokus pada penggunaan diksi, majas, dan citraan oleh penyair. Hasil analisis yang dilakukan Putri (2019) menunjukkan bahwa teks puisi menghadirkan suara ibu yang mengalami opresi oleh identitas pengibuan dan menghadirkan kompleksitas pengalaman ibu untuk meredefinisi identitas pengibuan melalui bahasa (diksi, majas, citra)

Sedangkan penelitian Novena, Suhita, \& Suryanto (2020) yang berjudul "Citra Perempuan dan Gaya Bahasa dalam Kumpulan Puisi Ibu Mendulang Anak Berlari sebagai Materi Pembelajaran Sastra" berfokus pada pemanfaatan citra perempuan dan gaya bahasa dalam kumpulan puisi Mendulang Anak Berlari karya Cyntha Hariadi sebagai materi bahan ajar pembelajaran sastra. Hasil penelitian menujukkan bahwa puisi dapat dijadikan sebagai materi ajar puisi di SMA karena tidak terdapat unsur sara ataupun melecehkan pihak tertentu. Selain itu gaya bahasa yang digunakan beragam seingga dapat dijadikan pembelajaran di sekolah.

Dari kedua penelitian atas kumpulan puisi Ibu Mendulang Anak Berlari itu terdapat perbedaan dengan penelitian ini. Pertama, pada penelitian Putri (2019) secara dominan berfokus pada makna pengibuan dan menggunakan teori semiotic language. Kedua, pada penelitian Novena, Suhita, \& Suryanto (2020), analisis pada citra perempuan hanya mengambil beberapa puisi sebagai sampel dan belum meyeluruh. Selain itu penelitian tersebut juga hanya sekadar mengungkap bentuk citra perempuan.

Dengan berangkat dari uraian latar belakang dan penelitian terdahulu, permasalahan yang diangkat pada penelitian ini ialah bagaimana bentuk citra perempuan dalam kumpulan puisi Ibu Mendulang Anak Berlari karya Cyntha Hariadi. Sesuai dengan permasalahan tersebut, penelitian ini bertujuan mengungkap citra perempuan dalam kumpulan puisi Ibu Mendulang Anak Berlari karya Cyntha Hariadi, yang meliputi citra fisik, citra psikis, dan citra sosial perempuan. Penelitian ini diharapkan dapat menunjukkan sisi feminitas dari penyair berdasarkan citra perempuan dalam puisi-puisi yang telah diciptakannya.

\section{LANDASAN TEORI}

Dalam karya sastra, seperti puisi, ditemukan bahwa ada citra atau gambaran-gambaran tertentu yang dimiliki perempuan dalam melukiskan dirinya sebagai individu yang mempunyai karakter tersendiri. Perempuan dapat digambarkan sebagai makhluk yang lemah lembut, penyayang dan memiliki sensitivitas lebih terhadap sesuatu dibanding laki-laki.

Citra diri perempuan merupakan salah satu unsur penting untuk menunjukkan siapa diri perempuan sebenarnya. Citra diri positif seseorang membuat dirinya berharga di mata orang lain. Citra diri yang lemah akan berakibat lanjut pada harga diri yang lemah. Mereka yang tergolong seperti ini selalu merasa dirinya tidak bernilai 
dalam mengarungi kehidupan (Mulawati, 2013).

Menurut Sugihastuti (2000) citra artinya 'rupa', 'gambaran' atau dapat berupa gambaran yang dimiliki orang banyak mengenai pribadi, atau kesan mental (bayangan) visual yang ditimbulkan oleh sebuah kata, frasa, atau kalimat, dan merupakan unsur dasar yang khas dalam karya prosa dan puisi. Dalam puisi, untuk memberi gambaran yang jelas, menimbulkan suasana khusus, membuat (lebih) hidup gambaran dalam pikiran dan penginderaan, dan menarik perhatian, penyair menggunakan gambarangambaran angan (pikiran) di samping alat kepuitisan yang lain. Gambaran dalam puisi sebagaimana dimaksud dinamakan citraan. Perempuan dicitrakan sebagai makhluk individu, yang beraspek fisis dan psikis, dan sebagai makhluk sosial yang beraspek keluarga dan masyarakat. Aspek-aspek ini terperinci atas dasar citra pemikiran terhadapnya.

\section{Citra Fisik Perempuan}

Perempuan adalah makhluk hidup yang mempunyai ciri-ciri fisik tertentu. Ciri-ciri fisik itu dapat berubah seiring bertambahnya usia pada diri perempuan. Secara fisis, perempuan dewasa merupakan sosok individu hasil bentukan proses biologis dari bayi perempuan, yang dalam perjalanan usianya mencapai taraf dewasa. Dalam aspek fisis ini, perempuan mengalami hal-hal yang khas, yang tidak dialami oleh pria, misalnya hanya perempuan yang dapat hamil, melahirkan, dan menyusui anak-anaknya (Sugihastuti, 2000).

Perempuan pada usia tertentu juga membuat berbagai keputusan karena karakteristik sekundernya sebagai ciri fisik. Karena tergantung dari apa yang menjadi ketentuan mengenai perempuan, ia harus memutuskan apa yang akan dilakukan karena ia mengalami siklus haid, atau karena buah dadanya mulai membesar. Tanda-tanda fisik yang mengantarkan anak perempuan menjadi perempuan dewasa ini memengaruhi pula perilaku yang dianggap pantas baginya sebagai perempuan dewasa (Sugihastuti, 2000).

Dengan ciri-ciri fisik tersebut, perempuan mempunyai tanggung jawab atas dirinya sendiri dan bagaimana ia menentukan sikap terhadap lingkungan. Dalam karya sastra, banyak ditemukan ciri-ciri fisik perempuan yang tergambarkan, baik secara tersirat atau tersurat. Selain dari aspek fisik kodrati perempuan, seperti memiliki buah dada, dapat melahirkan dan sebagainya, fisik perempuan juga dapat dikaitkan pada anggota tubuh yang lain yang mana biasanya menjadi sasaran ketidakadilan yang dilakukan oleh laki-laki terhadapnya karena fisik perempuan yang selalu dianggap lemah.

\section{Citra Psikis Perempuan}

Perempuan merupakan makhluk yang mempunyai perasaan, dapat berpikir, dan dapat mengekspresikan keinginan dan ketidakinginannya terhadap suatu hal atau lingkungan. Hal ini dapat tergambar juga melalui karya sastra yang bertemakan perempuan. Karya sastra bertema perempuan merupakan potret realitas mengenai perempuan. Biasanya karya sastra yang menceritakan atau menggambarkan diri perempuan tidak terlepas dari unsur feminitas dirinya sebagai perempuan. Menurut Sugihastuti (2000) ditinjau dari aspek psikisnya, perempuan juga makhluk psikologis, makhluk yang berpikir, berperasaan, dan beraspirasi.

Kejiwaan perempuan dewasa ditandai antara lain oleh sikap 
pertanggungjawaban penuh terhadap diri sendiri, bertanggung jawab atas nasib sendiri (Kartono, 1981). Dengan adanya aspek psikis yang dimiliki perempuan tersebut, perempuan dapat bereaksi terhadap sesuatu yang menimpa dirinya, baik dalam hal kasih sayang, bentuk perhatian atau bahkan ketidakadilan yang dialaminya. Perempuan bisa mengekspresikan dirinya atas kejadiankejadian yang menggugah perasaannya, seperti dapat gembira, sedih, menangis, bahkan memiliki rasa untuk memberontak dalam diri, bahkan menyimpan dendam. Biasanya perempuan memiliki ciri psikis yang lebih sensitif daripada laki-laki, maka dari itu lahirlah sebuah dogma dalam masyarakat yang mengatakan bahwa perempuan adalah makhluk lemah, tidak dapat berpikir secara rasional dan terlalu emosional terhadap sesuatu. Hal itu pula yang membuat perempuan kurang diterima atau kurang dihargai dalam lingkungan masyarakat dan mendapatkan perlakuan yang tidak menyenangkan dari individu lain seperti laki-laki.

\section{Citra Sosial Perempuan}

Perempuan sebagai makhluk sosial mempunyai perannya masing-masing terhadap lingkungan yang ia tempati. Wolfman (1994) mengungkapkan bahwa citra perempuan dalam aspek sosial disederhanakan ke dalam dua peran, yaitu peran perempuan dalam keluarga dan peran perempuan dalam masyarakat. Peran ialah bagian yang dimainkan seseorang pada setiap keadaan, dan cara bertingkah laku untuk menyelaraskan diri dengan keadaan.

Perempuan sebagai anggota keluarga dicitrakan sebagai makhluk yang disibukkan dengan berbagai aktivitas domestik kerumahtanggaan; banyak pekerjaan rumah tangga, yang dianggap sebagai tetek bengek, menjadi tanggung jawab perempuan. Dalam belenggu banyaknya pekerjaan domestik kerumahtanggaan itu, perempuan terhalang untuk berkembang sevara sosial, tetapi dalam peran seperti itu perempuan tetap berfungsi sesuai dengan aspek fisis dan psikisnya (Sugihastuti, 2000).

Manusia sebagai makhluk sosial dalam kehidupannya memerlukan manusia lain. Demikian juga bagi perempuan, hubungannya dengan manusia lain itu dapat bersifat khusus maupun umum tergantung pada bentuk sifat hubungannya itu. Hubugan manusia dalam masyarakat dimulai dari hubungan antarorang, termasuk hubungan antara perempuan dengan pria orang seorang (Sugihastuti, 2000).

Sugihastuti (2000) juga

menjelaskan bahwa citra sosial perempuan erat hubungannya dengan norma dan sistem nilai yang berlaku dalam satu kelompok masyarakat, tempat perempuan menjadi anggota dan berhasrat mengadakan hubungan antarmanusia. Selain itu, citra sosial perempuan juga merupakan masalah pengalaman diri, seperti dicitrakan dalam citra diri perempuan dan citra sosialnya. Pengalaman-pengalaman inilah yang menentukan interaksi sosial perempuan dalam masyarakat; atas pengalaman diri itulah perempuan bersikap, termasuk sikapnya terhadap laki-laki.

\section{Kritik Sastra Feminis}

Wiyatmi (2012) mengungkapkan bahwa kritik sastra feminis merupakan salah satu ragam dalam kajian sastra yang berdasarkan pemikiran feminisme yang menginginkan adanya keadilan dalam memandang eksistensi perempuan, baik sebagai penulis maupun karya-karya sastranya. Djajanegara 
(2000) berpendapat kritik sastra feminis berawal dari hasrat para feminis untuk mengkaji karya penulis-penulis perempuan di masa silam dan untuk menunjukkan citra perempuan dalam karya penulis-penulis pria yang menampilkan perempuan sebagai makhluk yang dengan berbagai cara ditekan, disalahtafsirkan, serta disepelekan oleh tradisi patriarkal yang dominan.

Sugihastuti dan Suharto (2005) mengungkapkan bahwa kritik sastra feminis ini dapat diartikan sebagai alat untuk menyatukan pendirian bahwa seorang perempuan dapat membaca sebagai perempuan, mengarang sebagai perempuan, dan menafsirkan karya sastra sebagai perempuan. Lebih lanjut, kritik sastra feminis dianggap sebagai sebuah kritik sastra yang memandang sastra dengan kesadaran khusus akan adanya perbedaan jenis kelamin yang banyak berhubungan dengan budaya, sastra, dan kehidupan manusia pada umumnya.

Dalam kritik sastra feminis, umumnya akan diamati sikap penulis yang mungkin menulis dengan kata-kata menyindir atau ironis, nada komik atau memperolok-olok, mengkritik atau mendukung, optimistis atau pesimistis. Nada dan suasana cerita pada umumnya mampu mengungkapkan maksud penulis dalam menghadirkan tokoh yang akan ditentang atau didukung para feminis. Untuk mengetahui pandangan serta sikap penulis, sebaiknya peneliti memperhatikan latar belakangnya karena tempat dan waktu penulisan sebuah karya sastra banyak mempengaruhi pendirian dan sikap seorang penulis (Rokhmansyah, 2016).

\section{METODE PENELITIAN}

Penelitian ini merupakan jenis penelitian kualitatif yang dipaparkan secara desktiptif. Pendekatan yang digunakan adalah pendekatan objektif dengan ancangan kritik feminisme. Sejalan dengan hal tersebut, penelitian ini berusaha mengungkap bentuk citra perempuan yang terkandung dalam puisi-puisi yang termuat pada kumpulan puisi Ibu Mendulang Anak Berlari karya Cyntha Hariadi.

Data penelitian berupa kutipankutipan puisi yang memuat kata atau frasa mengandung citra perempuan, baik citra fisik, psikis, maupun sosial. Data tersebut diperoleh dari puisi-puisi yang terdapat dalam kumpulan puisi $I b u$ Mendulang Anak Berlari. Adapun puisi yang dijadikan objek adalah 20 puisi, dengan pertimbangan kesesuaian dengan pemasalahan yang diangkat dalam penelitian. Kedua puluh puisi yang dijadikan objek, yaitu: (a) Anak Perempuan, (b) Kelahiran, (c) "Cium Kepalanya!", (d) Terbangun, (e) Payudara, (f) Lampu Rumah, (g) Sofa, (h) Dunia Kita Berbeda, (i) Mandi, (j) Susu, (k) Hotel, (l) Kaca, (m) Kosong, (n) Duduk dan Berpikir, (o) Pergulatan, (p) Pilihan, (q) Jalan-jalan, (r) Dua Aku, (s) Surga, dan (t) Ibu Mendulang Anak Berlari.

Teknik pembacaan pada tingkat pertama dilakukan untuk mendapatkan data yang kemudian dicatat dan ditabulasikan berdasarkan subkategori citra perempuan yang muncul. Data dianalisis dengan teknik analisis pembacaan retroaktif untuk memperoleh gambaran secara mendalam mengenai persoalan yang diangkat.

\section{PEMBAHASAN}

Buku kumpulan puisi Ibu Mendulang Anak Berlari karya Cyntha Hariadi memuat 62 puisi. Akan tetapi, dalam penelitian ini diambil 20 puisi, sebagaimana telah dipaparkan dalam metode penelitian. Dari hasil 
pengumpulan data, diperoleh data sebanyak 29 data. Aspek citra fisik ditemukan 6 data dari 5 puisi. Aspek psikis (batin) ditemukan 17 data dari 14 puisi. Aspek sosial ditemukan 6 data dari 4 puisi.

\section{Citra Fisik Perempuan}

Citra fisik perempuan adalah bentuk atau gambaran tentang diri perempuan dalam karya sastra dari segi fisik perempuan. Perempuan adalah makhluk hidup yang mempunyai ciri-ciri fisik tertentu. Ciri-ciri fisik itu dapat berubah seiring bertambahnya usia pada diri perempuan. Bentuk-bentuk citra fisik perempuan dalam puisi $I b u$ Mendulang Anak Berlarikarya Cyntha Hariadi dipaparkan pada data berupa kutipan baris dan bait puisi berikut.

\section{Data 1}

Kepala berkarak mendorong panggul kaki sudah lebam mendobrak nafas riuh megap-megap mengharap terang di balik gelap

\section{Ibu mengejan}

cengkramannya membelah gunung

(Hariadi, 2016, hlm. 2)

Data 1 merupakan kutipan puisi Kelahiran. Kalimat tersebut menggambarkan keadaan seorang perempuan yang sedang mengalami proses melahirkan. Dalam kutipan puisi tersebut digambarkan pula kesakitan yang dirasakan seorang perempuan saat melahirkan. Hal tersebut sangat tergambar pada bagian mendorong panggul. Perempuan yang sedang menjalani persalinan akan merasakan dorongan di dalam perutnya dari bayi yang akan keluar dari rahimnya.

Pada bagian kaki sudah lebam mendobrak juga menggambarkan fisik seorang perempuan yang tengah mempertahankan posisi kaki saat melahirkan. Perempuan yang tengah melahirkan umumnya tidak boleh menggerakkan kaki selama proses persalinan. Hal tersebut membuat perempuan merasa sakit di kakinya dan kemungkinan muncul lebam-lebam.

Kemudian pada bagian nafas riuh megap-megap juga menggambarkan keadaan seorang perempuan saat menjalani persalinan. Pada saat proses persalinan ini, seorang perempuan perlu mengatur nafasnya agar bayinya mudah lahir dan keluar dari rahim perempuan tersebut. Selain harus mengatur nafas, seorang perempuan juga harus mengejan. Hal ini digambarkan pula melalui bagian ibu mengejan.

Dari kutipan data 1 tersebut, penyair mencoba menggambarkan keadaan yang dialami oleh perempuan yang tengah melahirkan, penyair menyederhanakan gambaran proses melahirkan yang dialami oleh perempuan. Perempuan yang mengalami proses melahirkan bayi mengalami ciriciri tertentu, yaitu mengejan dan mengatur nafas, tetapi masih banyak proses yang harus dilalui perempuan ketika melahirkan, seperti pecahnya air ketuban, proses pembukaan rahim, sampai bayi keluar dari rahim perempuan.

Pada frasa puisi membelah gunung juga menggambarkan kesakitan fisik yang dialami oleh si ibu. Makna 'membelah gunung' adalah perihal yang sulit diterima oleh logika. Hal tersebut digunakan penyair menjadi metafora yang menggambarkan perjuangan seorang ibu dalam melahirkan anak.

Data 1 menunjukkan bahwa perempuan memiliki ciri fisik yang berhubungan dengan proses melahirkan. Ciri fisik ini ditandai dengan dimilikinya rahim dan saluran melahirkan. Hal ini menunjukkan bahwa perempuan normal 
memiliki Rahim dan saluran melahirkan, yang tentu berbeda dengan laki-laki.

Ciri fisik lain perempuan, selain rahim dan saluran untuk melahirkan (vagina), digambarkan pada data 2 puisi Terbangun. Kalimat dalam puisi itu dapat dilihat dalam kutipan berikut.

\section{Data 2}

kau telan putingku

sungai pun mengalir

tanah menggeliat

angin bergemuruh

(Hariadi, 2016, hlm. 4)

Data 2 menggambarkan keadaan fisik atau bagian tubuh lain yang dimiliki perempuan, yaitu payudara. Payudara perempuan sebagai organ fisik untuk menyusui seorang anak. Sebenarnya, laki-laki juga memiliki payudara. Meski sama-sama memiliki kelenjar payudara, anatomi dan fungsi kelenjar payudara pada perempuan dan laki-laki berbeda. Pada perempuan, kelenjar ini mulai berkembang pada masa pubertas karena meningkatnya hormon estrogen. Setelah itu, payudara perempuan akan mengalami perubahan struktur seiring perjalanan usia. Sementara pada lakilaki, kelenjar payudara tidak banyak berubah dari anak-anak hingga dewasa.

Perempuan yang telah melahirkan, umumnya mengeluarkan ASI (Air Susu Ibu). Pada perempuan, kelenjar payudara terdiri atas jaringan lemak, sekelompok lobulus, dan saluran duktus. Lobulus adalah kelenjar yang menghasilkan ASI. ASI yang diproduksi akan dialirkan melalui saluran ASI menuju puting. Kelenjar payudara laki-laki juga memiliki jaringan lemak dan duktus, tetapi tidak memiliki lobulus. Kemampuan perempuan untuk menghasilkan ASI inilah yang menunjukkan adanya ciri fisik perempuan yang berbeda dengan lakilaki. Hal ini digambarkan pada Data 2 baris pertama kau telan putingku dan baris kedua sungai pun mengalir. Baris kedua inilah yang menunjukkan adanya ASI di tubuh perempuan setelah melahirkan.

Dalam puisi tersebut digambarkan pula keadaan seorang ibu yang merasa air susunya telah mengalir dan dapat menghilangkan dahaga pada bayinya serta membuat bayinya merasa nyaman. Baris ketiga tanah menggeliat dan keempat angin bergemuruh merupakan metafora dari keadaan menyenangkan bagi si bayi tersebut karena telah berhasil menelan air susu ibunya.

Keadaan payudara perempuan juga digambarkan dalam kalimat yang dijadikan data 3 puisi. Kalimat dalam puisi berjudul Payudara dapat dilihat dalam kutipan berikut.

\section{Data 3}

Kupas kedua buah bundar ini ah buah payudara!

tak ada yang tak suka

hitam, coklat, kuning, putih, menggantung seperti apel, menggayut seperti mangga

atau melorot seperti pepaya

masing-masing ada penggemarnya

(Hariadi, 2016, hlm. 9)

Data 3 menggambarkan citra fisik perempuan. Citra fisik itu digambarkan dalam keadaan bentuk payudara perempuan yang beragam. Perempuan dalam puisi tersebut mempersilakan siapa saja untuk menikmati payudara yang beragam bentuknya. Bentuk payudara perempuan sangat beragam dan setiap perempuan memiliki bentuk payudara yang berbeda.

Penyair menggambarkan keadaan bentuk payudara yang beragam karena perempuan yang digambarkan juga beragam. Begitu pula fungsi payudara tersebut. Hal lain yang berkenaan 
dengan payudara dapat dilihat pada kutipan puisi Payudara di bawah ini.

\section{Data 4}

Buah ini suka bibir, tangan dan matamu kecuali pompa susu. (Hariadi, 2016, p. 9)

Data 4 masih menggambarkan payudara sebagai bentuk citra fisik perempuan. Pada Data 4, perempuan digambarkan sebagai sosok yang berharap anaknya lebih memilih buah dadanya sebagai sumber kehidupan daripada benda asing yang bernama pompa susu.

Kebanyakan perempuan lebih memilih menggunakan pompa susu sebagai alternatif untuk menyusui anaknya. Perempuan akan merasa pekerjaan tersebut lebih praktis karena jika menyusui anak dengan pompa susu, maka perempuan akan lebih banyak memiliki waktu untuk melakukan pekerjaan lainnya. Hal ini umumnya terjadi pada perempuan yang sangat sibuk dalam hari-harinya, biasanya perempuan tersebut adalah perempuan karier yang tidak memiliki cukup waktu untuk mengasuh bayinya.

Pompa susu juga akan menyebabkan bayi kebingungan dengan puting payudara sang ibu. Beberapa ibu mungkin menggunakan pompa payudara untuk memberikan ASI pada anak melalui botol susu. Padahal, penggunaan botol susu terlalu dini dapat menyebabkan bayi mengalami bingung puting. Sejak lahir bayi seharusnya mengenal tekstur, rasa dan bau dari payudara ibunya yang memberikan kenyamanan. Tetapi, jika perempuan terlalu sering memberinya botol susu, bayi mungkin saja akan menolak payudara sang ibu ketika menginginkan susu. Selain itu, penggunaan pompa payudara yang terlalu kencang bisa menyebabkan masalah jaringan payudara dan kerusakan puting. Oleh karena itu, seorang ibu harus memastikan pompa payudara tidak terlalu kencang dan pas dengan ukuran payudara. ${ }^{1}$ Dari uraian tersebut, penyair menggambarkannya pada Data 4 di atas.

Citra fisik perempuan dalam kumpulan puisi Ibu Mendulang Anak Berlari secara garis besar citra fisik perempuan didominasi oleh bentuk atau gambaran visual perempuan yang memiliki fisik yang difungsikan untuk memberikan kasih sayang kepada anaknya. Bentuk fisik perempuan dalam kumpulan puisi berupa vagina untuk melahirkan sebagaimana digambarkan pada Data 1 dan payudara untuk menyusui pada Data 2, Data 3, dan Data 4.

\section{Citra Psikis Perempuan}

Citra psikis (batin) perempuan adalah bentuk atau gambaran tentang diri perempuan dalam karya sastra dari segi psikis (batin) perempuan. Perempuan merupakan makhluk yang mempunyai perasaan, dapat berpikir, dan dapat mengekspresikan keinginan dan ketidakinginannya terhadap suatu hal atau lingkungan. Hal ini tergambar melalui karya sastra yang bertemakan perempuan. Biasanya karya sastra yang menceritakan atau menggambarkan diri perempuan tidak terlepas dari unsur feminitas dirinya sebagai perempuan.Bentuk-bentuk citra psikis (batin) perempuan dalam puisi $I b u$ Mendulang Anak Berlari karya Cyntha Hariadi dipaparkan pada data-data berupa kutipan baris dan bait puisi di bawah ini.

\section{Data 5}

${ }^{1}$ https://www.suara.com/health/2019/07/16/152000/ser ing-pakai-pompa-asi-cari-tahu-5-efek-sampingnyapada-payudara-dan-bayi?page $=$ all $($ diakses 20 November 2020). 
Aku anak perempuan ibuku

aku akan menjadi ibu anak perempuanku sang bibit

sang dara

yang kepadanya duniaku berderu.

...

Aku berhenti menyiram

aku ludahi kepala ibuku

sampai aku beranak

dan tak ingin jadi ibu.

(Hariadi, 2016, hlm. 1)

Data 5 adalah kutipan puisi Anak Perempuan tergambarkan keadaan batin perempuan yang mengalami trauma atau merasa takut jika ia akan seperti ibunya. Jika dilihat dari keseluruhan puisi Anak Perempuan, puisi tersebut menggambarkan keadaan seorang perempuan yang merasa takut perasaan batin ibunya akan dialaminya kelak memiliki anak perempuan juga. Perempuan itu merasa bahwa ia telah dibesarkan oleh seorang ibu dan menjadi kebanggaan ibunya, tetapi telah melukai hati ibunya. Ibunya telah memberikan segala hal walaupun harus berkorban demi anak perempuannya. Seorang perempuan dalam puisi tersebut merasa takut apabila ia mengalami hal yang sama ketika ia memiliki anak perempuan.

Puisi ini menggambarkan perasaan batin seorang perempuan suatu ketika akan mengalami keadaan yang pernah dirasakan oleh ibunya. Hal ini merupakan bentuk citra psikis perempuan yang umumnya mudah merasa cemas. Hal ini selaras dengan pendapat Maccoby dan Jacklin (1974) menyatakan bahwa perempuan lebih cemas dibanding dengan laki-laki. Perempuan menganggap bahwa kualitas hubungan interpersonal dengan orangorang di sekeliling mereka merupakan hal yang sangat penting dan merupakan prioritas hidup dibandingkan dengan laki-laki.

Citra psikis lain tergambar pada kutipan puisi "Cium Kepalanya!" sebagaimana dalam kutipan berikut.

\section{Data 6}

Namun matamu masih merambah

kapan kau akan melihatku?

Handuk hijau yang membungkusmu, lebih hangatkah daripada tubuhku?

(Hariadi, 2016, p. 4)

Dari kutipan puisi tersebut, citra batin perempuan yang digambarkan adalah keadaan batin seorang perempuan yang baru saja mengalami proses persalinan, perempuan merasa takjub kepada anak yang baru saja ia lahirkan. Perempuan ingin anaknya segera melihatnya. Setelah proses persalinan selesai, si ibu dipisahkan oleh bayinya. Bayi tersebut dibungkus oleh handuk hijau, sesuai pada isi kutipan, untuk menghangatkan bayinya.

Kemudian perempuan berangan untuk segera dapat memeluk anaknya. Ibu merasa kuatir bahwa handuk yang membungkus bayinya tidak cukup untuk menghangatkan bayinya. Keadaan perempuan yang merasa sangat bahagia usai melahirkan adalah hal yang sangat wajar dialami perempuan, umumya setiap ibu selalu merasakan itu. Pengorbanan dan penantiannya selama kurang lebih sembilan bulan terbayarkan oleh memiliki bayi.

Citra psikis yang digambarkan penyair pada puisi tersebut adalah citra batin perempuan yang mengalami kecemasan usai persalinan. Kasih sayang ibu kepada anaknya membuatnya tidak ingin jauh dari anaknya dan selalu berhasrat untuk melindungi anaknya secara langsung, yakni mealalui dekapan kasih sayang.

Pada puisi Lampu Merah juga terdapat gambaran citra psikis 
perempuan, sebagaimana dalam kutipan berikut.

\section{Data 7}

Seharian

aku menunggu

menyalakan lampu-lampu rumah

ketika bayangan mengekor cahaya

melahirkan ilusi aku berada di rumah

bukan di penjara.

(Hariadi, 2016, hlm. 11)

Dari kutipan puisi tersebut, citra batin perempuan yang digambarkan adalah sosok perempuan yang merasa tertekan dan jenuh oleh pekerjaan yang ia lakukan. Perempuan dalam puisi tersebut digambarkan sedang menunggu suaminya pulang ke rumah. Perempuan menyalakan lampu-lampu rumah pertanda bahwa hari sudah petang. Pekerjaan tersebut adalah tugasnya di dalam rumah. Menyalakan lampu rumah juga dapat diartikan sebagai simbol yang mewakili pekerjaan rumah tangga lainnya, seperti memasak, mencuci, menyapu, dan sebagainya.

Seperti yang kita tahu bahwa umumnya perempuan Indonesia didominasi oleh pembagian tugas rumah tangga usai perkawinan dengan berada di dalam rumah dan bekerja di dalamnya. Dalam kutipan juga dijelaskan bahwa keadaan batin perempuan yang merasa sedih dan tertekan sehingga saat perempuan melakukan pekerjaan rumah (menyalakan lampu-lampu rumah), dalam puisi dikatakan Melahirkan ilusi aku berada di rumah, bukan di penjara. Penjara adalah sebuah tempat yang menyedihkan sekaligus mengerikan, kira-kira begitulah bayangan yang ada di dalam batin perempuan dalam puisi sehingga perempuan seperti menghibur diri saat menyalakan lampu-lampu rumah dari keadan gelap berubah menjadi terang, memberikan harapan dalam hati perempuan yang tertekan. Meskipun semua bertolak dengan apa yang dirasakan oleh perempuan, perempuan merasa tidak dapat bebas dan tetap harus patuh kepada suami, menunggu dan bekerja di dalam rumah.

Keadaan psikis perempuan dalam rumah tangga juga dapat dilihat pada Data 8 yang merupakan penggalan kalimat dari puisi Sofa. Kalimat itu dapat dilihat dalam kutipan berikut.

\section{Data 8}

yang besar melirik yang kecil

yang kecil menggigil

yang besar menggapaikan tangan

hiu menyambarnya

yang kecil menangis

yang besar meringis

Dua orang duduk di sofa

lima bulan tidak bersua.

(Hariadi, 2016, hlm. 21)

Data tersebut menggambarkan keadaan seorang perempuan yang merupakan seorang istri sedang bertemu dengan suaminya. Suami-istri ini digambarkan lama tidak bertemu sebagaimana baris lima bulan tidak bersua. Perempuan merasa cemas ketika suaminya mulai "menyambar" atau merengkuh istrinya. Pada baris yang kecil menangis dimaknai sebagai keadaan seorang perempuan yang pasrah direngkuh oleh laki-laki atau suaminya. Kemudian sebaliknya, pada baris yang besar meringis menggambarkan keadaan seorang suami yang tengah berbahagia atau merasa puas karena telah menguasai diri perempuan (istrinya).

Perempuan yang menangis dapat diartikan sebagai tanda bahwa keadaan emosional perempuan sedang tidak baik. Keadaan emosional ini dapat disebabkan oleh rasa haru dan bahagia dapat melepas rindu dengan suaminya. Akan tetapi, juga dapat diartikan sebagai 
luapan rasa takut apabila suatu saat nanti berpisah kembali dengan suaminya.

Hal yang masih berkaitan dengan hubungan kerumahtanggaan dapat ditemukan pada data 9 yang merupakan kutipan puisi yang berjudul "Dunia Kita Berbeda."

\section{Data 9}

Lampu bertopi merah berpendar kuning menerangi kata-kata yang aku baca temaram di wajahmu yang kedap-kedip minum susu

hitam di atas wajah ayah yang tertidur entah karena capai pulang kerja, atau jenuh mendengar cerita seribu satu malam

yang terlalu jauh dari dunianya namun rela aku selami setiap malam karena indah jauhnya.

(Hariadi, 2016, hlm. 25)

Dalam Data 9, digambarkan keadaan batin seorang perempuan yang penuh kasih sayang dan mengekspresikan itu semua lewat kesabaran dan ketekunannya yang dicurahkan untuk anak dan suaminya. Perempuan dalam puisi digambarkan tengah membacakan dongeng untuk anaknya yang sedang minum susu dan berada di atas tubuh ayahnya yang tertidur pulas karena merasa lelah setelah pulang kerja. Perempuan dalam puisi digambarkan sebagai ibu atau istri yang patuh dalam persoalan rumah tangga. Meskipun dalam keadaan larut dan sudah waktunya untuk beristirahat, perempuan dengan penuh kesabaran tetap mengasuh anak dengan baik.

Perempuan dalam puisi digambarkan merasa lelah karena telah mengurus pekerjaan rumah sehari penuh dan mengasuh anak dan perempuan masih dibebankan pekerjaan hingga larut malam bahkan saat suami sudah mengakhiri aktivitasnya seharian (bekerja di luar) dengan tidur di rumah.
Baris terakhir Data 9 menandakan bahwa perempuan berusaha untuk menghibur dirinya sendiri dengan buku dongeng yang ia bacakan untuk anaknya. Isi dongeng yang biasanya selalu berakhir indah membuat perempuan atau ibu yang membacanya ikut terbawa dan dapat sejenak melupakan lelahnya karena seharian harus memenuhi pekerjaan rumah, juga mengasuh anak dan melayani suami.

Citra psikis (batin) perempuan dalam kumpulan puisi Ibu Mendulang Anak Berlari karya Cyntha Hariadi secara garis besar didominasi oleh bentuk psikis (batin) seorang perempuan yang memiliki peran dalam rumah tangga dengan mencurahkan kasih sayangnya kepada anak dan suaminya. Perempuan digambarkan sebagai sosok yang sabar dan rela berkorban serta sebagai pelayan yang baik untuk anak dan suaminya, sebagaimana tergambar pada data $6,7,8$, dan 9. Tetapi, ada pula gambaran terkait perasaan perempuan lebih sering mengalami kecemasan, sebagaimana tergambar pada data 5 .

\section{Citra Sosial Perempuan}

Citra sosial perempuan adalah citra perempuan yang erat kaitannya dengan norma dan sistem nilai yang berlaku dalam satu kelompok masyarakat, tempat perempuan menjadi anggota dan berhasrat mengadakan hubungan antarmanusia (Diana, 2018). Citra sosial perempuan adalah bentuk atau gambaran tentang diri perempuan dalam karya sastra dari segi kehidupan sosial perempuan. Perempuan sebagai makhluk sosial mempunyai perannya masingmasing terhadap lingkungan yang ia tempati. Citra sosial perempuan juga menggambarkan keadaan seorang perempuan dalam perannya di rumah tangga, baik sebagai ibu maupun istri. 
Bentuk-bentuk citra sosial perempuan dalam puisi Ibu Mendulang Anak Berlari Karya Cyntha Hariadi dipaparkan pada data berupa kutipan baris dan bait puisi di bawah ini.

\section{Data 10}

Seorang ibu mencari angin segar sandalnya menggerus aspal melewati taman, toko, restoran, apartemen, gerobak jualan potongan mangga dan sate daging.

Seekor anjing berbelok di tikungan tanpa tujuan, ibu berbelok juga. (Hariadi, 2016, hlm. 46)

Dari kutipan puisi Hotel tersebut, citra sosial perempuan yang tergambar adalah keadaan seorang perempuan yang berstatus sebagai ibu sedang keluar rumah untuk mencari angin segar. Dalam hal ini angin segar dapat didefinisikan sebagai sebuah pelarian perempuan dari rumahnya dan keluarganya untuk sekadar menenangkan diri dari rutinitas harian seperti yang umum dilakukan oleh perempuanperempuan yang sudah berkeluarga atau berumah tangga. Ibu dalam puisi digambarkan sedang berjalan di jalan raya, melewati keramaian seperti yang digambarkan dalam puisi: melewati toko, restoran, apartemen, gerobak jualan potongan mangga dan sate daging. Selanjutnya dalam kutipan kata terakhir, ibu digambarkan tidak memiliki tujuan pasti akan ke mana ia berjalan, ia hanya mengikuti arus saja. Dan yang terpenting bagi perempuan dalam puisi, ia dapat keluar dari rumah, dan dapat sedikit melegakan perasaannya.

Peran perempuan dalam rumah tangga adalah peran sosial yang umum disandang perempuan di Indonesia. Biasanya perempuan melaksanakan tugas dan perannya dalam rumah tangga seperti mengurus rumah, mengasuh anak sampai melayani suaminya. Tidak dapat dielakkan bahwa setiap manusia bisa saja jenuh dengan segala aktivitas yang biasa ia lakukan. Begitu pun yang dialami perempuan dalam rumah tangga. Sekadar keluar rumah dan berjalan-jalan merupakan alternatif pelarian dari rasa jenuh dan stres dari lingkungan sosial rumah tangga ke lingkungan masyarakat.

Hal lain tentang keadaan seorang perempuan yang berperan dalam keadaan sosial tergambar pada Data 11 kutipan puisi Kaca berikut.

\section{Data 11}

Ia bilang ibunya penulis, ayahnya pemilik koran.

Ia sekolah di sekolah prestisius dan ibunya terkenal.

Ia tidak tahu aku bermimpi bisa menulis seperti ibunya

dan membiarkan anakku dikasihani orang seperti aku mengasihaninya.

(Hariadi, 2016, p. 50)

Pada Data 11 di atas, citra sosial yang tergambar adalah keadaan seorang perempuan yang tengah merasa kasihan terhadap anak perempuan dari penulis perempuan. Anak itu merasa sedih karena tidak dijemput ibunya di sekolah. Ibu dari anak perempuanitu ibu yang sibuk atau perempuan karir. Ibu anak itu berprofesi sebagai penulis yang terkenal. Kesibukan sebagai penulis menjadikannya lalai kepada anak yang seharusnya mendapatkan kasih sayang dari seorang ibu. Dari puisi Kaca terlihat bahwa perempuan sukses akan sibuk dan umunya menelantarkan anaknya. Oleh sebab itu, posisi ibu akan digantikan oleh pengasuh, sebagaimana terlihat pada Data 12 berikut yang juga berasal dari puisi Kaca.

\section{Data 12}

... 
Ia duduk bersila di sampingku, dengkulnya tak bisa diam.

Aku cuma ketemu ibuku di pagi hari, sahutnya.

Suaranya manis seperti sedang cerita ia punya kucing.

Kutanya siapa yang menidurkannya

Dia, kata si manis menunjuk pengasuhnya yang duduk bergeming terinjak derap kaki-kaki kecil dari dalam kelas.

(Hariadi, 2016, p. 50)

Pada Data 12 tersebut, terlihat bahwa gambaran citra sosial perempuan yang akan meninggalkan anaknya dan diserahkan ke orang lain-pengasuh. Citra sosial perempuan yang tergambar adalah bahwa seorang perempuan biasanya-yang sudah merasa sukses, akan cenderung mengabaikan anaknya, dan memilih anaknya diasuh oleh orang lain karena kesibukan yang tidak dapat ia tinggalkan. Perempuan tidak dapat mengatur atau membagi pekerjaan atau urusan rumah tangga dan karir. Dampak yang terjadi akibat perempuan menjadi perempuan karier adalah harus mengorbankan anak yang masih kecil atau masih membutuhkan kasih sayangnya sebagai seorang ibu, sebab anak terbiasa dekat dengan ibu, tidak dengan ayah, oleh sebab itulah ia merasa keberatan jika ibunya yang bekerja di luar rumah (publik).

Citra sosial perempuan dalam kumpulan puisi Ibu Mendulang Anak Berlari karya Cyntha Hariadi secara garis besar didominasi oleh bentuk gambaran visual perempuan yang memiliki peran sebagai ibu rumah tangga yang selalu harus mengasuh serta melayani anak dan suami dengan baik. Perempuan sebagai makhluk sosial dalam puisi juga digambarkan sebagai perempuan yang aktif dalam kehidupan sosial seperti menjadi perempuan karier dan juga terlibat dalam lingkungan rumah tangga.

\section{PENUTUP}

Berdasarkan analisis yang telah dilakukan, ada tiga citra perempuan terdapat dalam kumpulan puisi $I b u$ Mendulang Anak Berlari karya Cyntha Hariadi. Pertama, citra fisik perempuan meliputi penggambaran organ biologis perempuan saat mengalami proses kehamilan, persalinan, serta menyusui anaknya. Kedua, citra psikis (batin) perempuan meliputi penggambaran perempuan yang mengalami keadaan psikis seperti merasa sedih, cemas, takut, gembira dan keadaan emosional lainnya. Ketiga, citra sosial perempuan meliputi penggambaran perempuan sebagai makhluk sosial serta perannya dalam keluarga dan masyarakat.

Citra perempuan yang dimunculkan oleh pengarang dalam kumpulan puisi Ibu Mendulang Anak Berlari menunjukkan adanya upaya pengarang untuk menyampaikan eksistensi perempuan di dalam kehidupan. Berkaitan dengan usahanya itu, ditunjukkan bahwa pengarang ingin posisi perempuan diakui dan dihargai keberadaannya. Pengarang juga ingin menyampaikan hal terkait posisi perempuan yang berperan sebagai seorang Ibu, baik di dalam keluarga maupun di masyarakat

\section{DAFTAR PUSTAKA}

Diana, J. (2018). Citra sosial perempuan dalam cerpen Kartini karya Putu Wijaya: Tinjauan kritik sastra feminis. Jurnal Pena Indonesia, 4(1), 79-96.

Djajanegara, S. (2000). Kritik sastra feminis: Sebuah pengantar. 
Jakarta: Gramedia Pustaka Utama.

Hariadi, C. (2016). Ibu mendulang anak berlari. Jakarta: Gramedia Pustaka Utama.

Kartono, K. (1981). Psikologi wanita. Bandung: Alumni.

Maccoby, E. M., \& Jacklin, C. N. (1974). The psychology of sex differences. California: Stanford University Press.

Mulawati. (2013). Citra diri Laisa dalam novel bidadari-bidadari surga. Kandai, 9(1), 82-95. Retrieved from

https://ojs.badanbahasa.kemdikbu d.go.id/jurnal/index.php/kandai/a rticle/view/285

Novena, Y. K., Suhita, R., \& Suryanto, E. (2020). Citra perempuan dan gaya bahasa dalam kumpulan puisi ibu mendulang anak Berlari sebagai materi pembelajaran sastra. BASASTRA: Jurnal Bahasa, Sastra, Dan Pengajarannya, 8(1), 195-205.

Putri, D. J. (2019). Kompleksitas makna pengibuan (Kajian teks kumpulan puisi ibu mendulang anak berlari karya Cyntha Hariadi). Universitas Indonesia.

Rokhmansyah, A. (2016). Pengantar gender dan feminisme: Pemahaman awal kritik sastra feminisme. Yogyakarta: Garudhawaca.
Sugihastuti. (2000). Wanita di mata wanita: Perspektif sajak-sajak Toeti Heraty. Bandung: Nuansa Cendikia.

Sugihastuti, \& Suharto. (2005). Kritik sastra feminis: Teori dan aplikasinya. Yogyakarta: Pustaka Pelajar.

Syahrul, N. (2013). Citra perempuan dalam kaba anggun nan tungga karya Ambas Mahkota. Jentera: Jurnal Kajian Sastra, 2(2), 3952.

https://doi.org/10.26499/jentera.v $2 \mathrm{i} 2.407$

Wendra, I. W. (2010). Citra perempuan dalam sastra modern (Sebuah pandangan feministik pada dua pengarang laki-laki). Jurnal IKA, 8(1), 15-24.

Wiyatmi. (2012). Kritik sastra feminis: Teori dan aplikasinya dalam sastra Indonesia. Yogyakarta: Ombak.

Wolfman, B. R. (1994). Peran kaum wanita. Yogyakarta: Kanisius. 